\title{
An updated insight into the natural attenuation of As concentrations in Reigous Creek (southern France)
}

\author{
Marion Egal $^{3 *}$, Corinne Casiot ${ }^{3}$, Guillaume Morinb, Françoise Elbaz-Poulichet ${ }^{3}$, \\ Marie-Ange Cordier ${ }^{3}$, Odile Bruneel ${ }^{3}$ \\ *Hydrosciences UMR 5569, CNRS. Universités Montpellier I and II. IRD, Place Eugène Bataillon. CC MSE. 34095 Montpellier cedex 5. France \\ ${ }^{h}$ Institut de Minéralogie et de Physique des Milieux Condensés (IMPMC), UMR 7590 CNRS, Université Paris 6 and 7 - /PCP, Bâtiment 7, ler étage, Campus Boucicaut, \\ 140 rue de Lounnel, 75015 Paris, France
}

\begin{abstract}
A B S T R A C T
The removal of metals and metalloids occurring in acid mine drainage has been studied on different scales (years, days). Dissolved and particulate concentrations of Fe and As were monitored over a 4-a period along Reigous Creek, an acid mine drainage from a former $\mathrm{Pb}-\mathrm{Zn}$ mine in southern France. Dissolved concentrations of $\mathrm{Fe}\left(12-25 \mathrm{mmol} \mathrm{L}^{-1}\right)$, As $\left(0.9-3.5 \mathrm{mmol} \mathrm{L}^{\prime \prime}\right)$ and $\mathrm{S}_{0} 4^{-}\left(10-70 \mathrm{mmol} \mathrm{L}^{-1}\right)$ exhibited seasonal variations related to rainfall, with an increase during the driest months. About $30 \%$ of the As initially present in solution as As(111) was coprecipitated with Fe oxides in the first $40 \mathrm{~m}$ of Reigous Creek. The corresponding As removal rate was $3.58 \times 10^{-7} \mathrm{~mol} \mathrm{~L}^{-1} \mathrm{~S}^{\prime \prime} \backslash$ The mineralogy of resultant precipitates varied spatially and seasonally. Over the first $40 \mathrm{~m}$, amorphous $\mathrm{As}(\mathrm{V})-\mathrm{Fe}(\mathrm{III})$ phases and tooeleite, were formed. Sediments deposited in the bed of the creek close to the spring contained both types of solid phases. Laminated concretions, which consist of precipitates around bacterial structures, were mainly constituted of tooeleite. Further downstream, these Fe-oxide phases were replaced by schwertmannite and ferrihydrite. On a daily basis, concentrations of dissolved $\mathrm{Fe}$ and As have been shown to vary up to $10 \%$ during the day as a result of photoreduction of Fe-oxide phases.
\end{abstract}

\section{Introduction}

Arsenic is a highly toxic element that is released into water by natural processes as well as by human activity (Smedley and Kinniburgh, 2002). The biogeochemical processes controlling the fate of As in water have consequently been widely studied. These studies have shown that As mobility is limited by its ability to bind to solid oxide phases such as Fe oxides and to a lesser extent to Al hydroxides (Masue et al,, 2007, and references therein).

In water, inorganic As may occur as arsenate $(\mathrm{As}(\mathrm{V}))$ and arsenite $(\operatorname{As}(111))$. The adsorption of As onto Fe oxides depends on $\mathrm{pH}$ and on As spéciation. Arsenate adsorbs strongly to Fe-oxide surfaces in acidic and near-neutral-pH water (Dzombak and Morel, 1990; Waychunas et al., 1993). Adsorption experiments by Raven et al. (1998) also indicated greater adsorption of arsenate than of arsenite at $\mathrm{pH}$ values below 6-7.5 with a relatively low initial As/ $\mathrm{Fe}$ molar ratio (0.024-0.071). With a higher initial $\mathrm{As} / \mathrm{Fe}$ ratio (1.18), arsenite adsorption is at a maximum at approximately $\mathrm{pH}$ 9 and greater than that of arsenate, which decreases continuously from $\mathrm{pH} 3$ to 11 . Other parameters such as concentrations of the

\footnotetext{
* Corresponding author. Fax: +33 467144774.

E-mail address: egal@ mseni.univ-montp2.fr (M. Egal).
}

major ions and the nature of the Fe mineral phases also influence As sorption on Fe oxides (Raven et al,, 1998; Jain et al., 1999; Pedersen, 2006; Banerjee et al., 2008).

Mining of some metal ores results in large quantities of sulfiderich wastes that often contain high concentrations of As. The oxidation of these wastes by meteoric water can generate $\mathrm{Fe}$ and As-rich acid mine drainage (AMD), and subsequent precipitation of Fe oxyhydroxide phases as a function of $\mathrm{pH}$. As $\mathrm{pH}$ rises the following sequence of minerals has been observed: jarosite $\mathrm{KFej}(\mathrm{S} 04)_{2}(\mathrm{OH})_{6}$, schwertmannite $\mathrm{Fe} 808(\mathrm{OH})_{6} \mathrm{SO}$, ferrihydrite $\mathrm{Fe}_{5}(\mathrm{OH})_{8} \cdot 4 \mathrm{H} 20$, goethite $\mathrm{cx}-\mathrm{FeOOH}$, or lepidocrocite $\mathrm{y}-\mathrm{FeOOH}$, as a function (Bigham et al., 1996a). These Fe oxides are efficient in scavenging As by adsorption (Fukushi et al., 2003, 2004; Jônsson and Sherman, 2008) or coprecipitation (Carlson et al., 2002; Morin et al., 2003; Pedersen et al., 2006). The reduction of the Fe-oxyhydroxides can subsequently release As into solution. In AMD surface water, conditions are generally oxidizing, however Fe photoreduction can take place causing diel variations in dissolved As concentrations (Fuller and Davis, 1989; Nimick et al,, 2005; Karlsson et al,, 1995; Tate et al., 1995).

In Reigous Creek, which drains the tailings impoundment of the Carnoulès mine, the precipitation of Fe oxides is linked to bacterial activity and As is removed through coprecipitation (Bruneel et al,, 2003; Casiot et al,,2003; Duquesne et al., 2003). Depending on the 
location, precipitation of $\mathrm{Fe}$ (III)-As(III) (tooeleite) nano-crystals and/or amorphous Fe(III)-As(V) was observed (Casiot et al., 2003; Morin et al,, 2003). These data from 1-year monitoring studies of water composition provided evidence for seasonal variations in As removal by Fe oxides, with the highest removal being recorded in winter. However, these studies did not cover a complete hydrological cycle and uncertainty remains regarding the relationship between the hydrologic conditions and $\mathrm{Fe}$ and As removal. Hydrological conditions vary drastically from season to season and from year to year in a Mediterranean climate and further investigation was necessary to resolve the relationship between the hydrologic conditions and $\mathrm{Fe}$ and As removal.

The present study was undertaken to better characterize the variability of dissolved As concentrations in Reigous Creek over different time scales and to gain more insight than was previously possible into the processes that control As removal in Reigous Creek. To this end, the concentrations of $\mathrm{As}(\mathrm{III}), \mathrm{As}(\mathrm{V})$, total dissolved As (AsT), $\mathrm{Fe}(\mathrm{II})$ and total dissolved $\mathrm{Fe}$ (FeT) together with some selected physicochemical parameters (temperature, rainfall, redox potential, light intensity, dissolved $02, \mathrm{SO}_{4}^{2-}$ ) were determined over different time scales (diurnal, seasonal, interannual). The concentrations of particulate $\mathrm{As}$ and $\mathrm{Fe}$ and the mineralogy of solid phases were also determined.

\section{Site description}

The Carnoulès $\mathrm{Pb}-\mathrm{Zn}$ mine is located in southern France in the drainage basin of the Gardon d'Anduze, a tributary of the Rhone River (Fig. 1). The mine, which was abandoned in 1963, produced 1.2 MT of spoil material containing quartz, sulfide minerals, metals $(\mathrm{Pb}, \mathrm{Zn}, \mathrm{TI})$ and $\mathrm{As}$. The material was deposited behind a dam.

The hydrogeological and biogeochemical conditions of the Carnoulès spoil heaps that generate As-rich AMD have been characterized in several studies (Casiot et al., 2003; Koffi et al., 2003; Bruneel et al., 2005). AMD is generated at the base of the tailings stock where 02-rich water that drains from the surroundings penetrates during rainfall events. The groundwater of the tailings stock is characterized by exceptionally high As concentrations of up to $1 \mathrm{gL}^{-1}$ (i.e. $13 \mathrm{mmol} \mathrm{L}^{-9}$ ).

The water emerges at the bottom of the dam forming the source of Reigous Creek (station S), at a flow rate of $0.8-1.7 \mathrm{Ls}^{-1}$. The

(a)

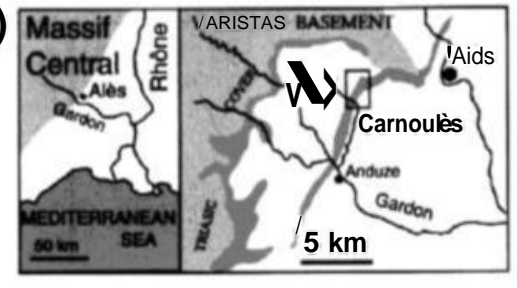

(b)

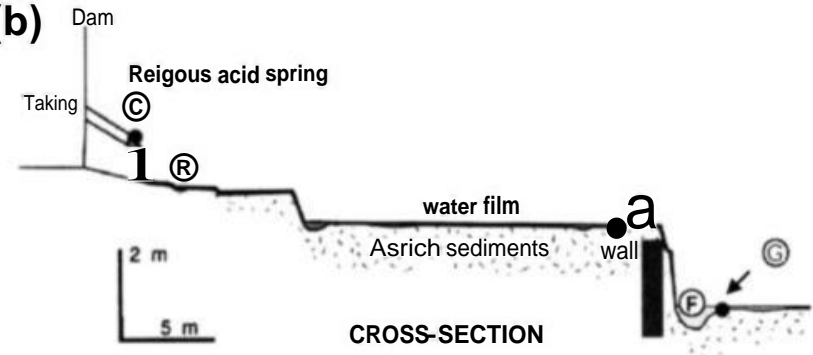

Fig. 1. Location of the study area and sampling stations along Reigous Creek. (a) General maps and (b) cross section of the first $40 \mathrm{~m}$ of Reigous Creek. water is acidic (pH 2-3) and rich in dissolved $\mathrm{Fe}$ and $\mathrm{As}$ ( $[\mathrm{Fe}]-0.5-1 \mathrm{gL}^{-1}$ i.e. $9-18 \mathrm{mmol} \mathrm{L}^{-1}$; [As ] $=50-350 \mathrm{mgL}^{-1}$ i.e. 0.7-4.7 $\mathrm{mmol} \mathrm{L}^{\sim}$ ) predominantly in the reduced forms, $\mathrm{Fe}(\mathrm{II})$ and As(III) (Casiot et al., 2003). Over the first $\mathbf{4 0 ~} \mathrm{m}$ of the creek, the addition of seepage water is negligible and large amounts of $\mathrm{Fe}$ precipitates forming laminated orange to yellow concretions that accumulate around bacterial structures and contain up to $20 \%$ wt. of As (Leblanc et al,, 1996). At a distance of $150 \mathrm{~m}$ from its source (station Gal), the Reigous receives water from a small Fe-rich tributary, the Ru Gal. Before the confluence with the Amous River 1.5 km downstream from its source (station Reigous UC), Reigous Creek also receives inputs from quarries and mine galleries.

\section{Materials and methods}

The location of sampling stations in Reigous Creek is shown in Fig. 1. During the long term monitoring programme, water samples were taken monthly from November 2004 to 2008 at four stations located along Reigous Creek. Hourly variations in water physicochemistry over a diurnal cycle were monitored during a $36 \mathrm{~h}$ survey that was conducted at station G, on the 9th and 10th of May 2007.

The $\mathrm{pH}$, temperature, conductivity and redox potential (Eh) were measured in the field with an Utrameter ${ }^{\mathrm{TM}}$ model $6 \mathrm{P}$ (Myron L Company, Camlab, Cambridge). Dissolved 02 (DO) was measured with CHEMets ${ }^{\prime \prime}$ tests (CHEMetrics, Calverton, USA) based on colorimetric detection after reaction of DO with indigo carmine for the $0-12 \mathrm{pgg}^{-1}$ range and with rhodazine $D$ for $0-1 \mathrm{pgg}^{-1}$ range.

Water samples were filtered immediately after collection through $0.22 \mathrm{pm}$ Millipore polycarbonate membranes fitted on Sartorius polycarbonate filter holders. One aliquot was immediately acidified to $\mathrm{pH} 1$ with HNO3 Merck Suprapur and stored at $4{ }^{\circ} \mathrm{C}$ for the determination of total dissolved Fe (FeT). Another aliquot was taken for determination of $\mathrm{Fe}$ (II). It was buffered to $\mathrm{pH}$ 4.5 with an ammonium acetate/acetic acid buffer immediately after filtration and $\mathrm{Fe}(\mathrm{II})$ was complexed by adding $1 \mathrm{~mL}$ of a $0.5 \%(w / w) 1,10$-phenanthrolinium chloride solution to $10 \mathrm{~mL}$ of sample (Rodier et al., 1996). Samples for As spéciation were preserved with $5 \%$ EDTA $0.25 \mathrm{M}$, as recommended by Bednar et al. (2002), and deep frozen until analysis. The samples for the determination of $\mathrm{SO}_{4}^{2-}$ were also deep frozen.

Total Fe was determined by Flame Atomic Absorption Spectrometry (FAAS). Iron(II) concentrations were determined using spectrophotometry at $510 \mathrm{~nm}$, and $\mathrm{Fe}$ (III) was calculated by the difference between total $\mathrm{Fe}$ and $\mathrm{Fe}$ (II). Total As was determined by Inductively Coupled Plasma-Mass Spectrometry (1CP-MS, PQ 2+, VG-elemental, Fisons or X Series, Thermo). The elevated As concentrations required dilution. The dilution was done by introducing an aliquot of the initial sample into Milii- $Q$ water (Millipore ${ }^{\circledR}$ ) and which was then acidified $(1 / 1000 \mathrm{v} / \mathrm{v})$ with $\mathrm{HNO}_{3}$ (Merck Suprapur). No interference due to $\mathrm{ArCl}$ was detected. 1 CP-MS was calibrated using peak intensity, acquired in peak jump mode, with standard solutions. Indium-115 was used as internal standard to correct for changes in peak intensities due to instrumental drift. Inorganic As spéciation analyses were carried out using anion-exchange chromatography $(25 \mathrm{~cm} \times 4.1 \mathrm{~mm}$ i.d. Hamilton PRP-X 100 column with Varian ProStar gradient solvent delivery system) coupled to Hydride Generation (HG) (VGS 200, FISONS, France) with Atomic Fluorescence Spectrometry (AFS) detector (Excalibur, PSAnalytical, GB) (Casiot et al., 2005). The detection limit was $0.17 \mathrm{pg} \mathrm{L}^{-1}$ (i.e. $2.27 \mathrm{nmol} \mathrm{L}^{-1}$ ) for $\mathrm{As}(\mathrm{III})$ and $0.46 \mathrm{pg} \mathrm{L}^{-1}$ (ie. $6.13 \mathrm{nmol} \mathrm{L}^{-1}$ ) for $A s(V)$ with a precision of $>5 \%$. Sulfate concentrations were determined after precipitation with $\mathrm{BaCl}_{2}$ and stabilisation with polyvinyl-pyrrolidone by nephelometry with a spectrophotometer at $650 \mathrm{~nm}$ (Rodier et al., 1996). 
Precipitates were sampled over a period of 18 months between May 2006 and February 2008. Three different types of precipitates were collected: sediments (fine particles deposited at the bottom of the stream), laminated concretions made of sediments precipitated around bacterial structures, and sediments that undergo periods of drying when they are temporarily out of the water during low flow periods. The precipitates were dried under vacuum. They were then dissolved in a microwave oven using $10 \mathrm{~mL}$ of HNO3 (Merck Suprapur) for $50 \mathrm{mg}$ sample following the 3051 EPA protocol with slight modifications. The microwave oven programme consisted of two steps: increasing the temperature for $15 \mathrm{~min}$ from ambient to $500{ }^{\circ} \mathrm{C}$ followed by $15 \mathrm{~min}$ at $500{ }^{\circ} \mathrm{C}$. Total As and Fe concentrations were determined by ICP-MS as described for the aqueous phase. The mineralogical composition of the solid samples was determined by X-ray powder diffraction (XRD) using Co Kot radiation. Data were recorded over a 20 range of $5-85^{\circ}$ with
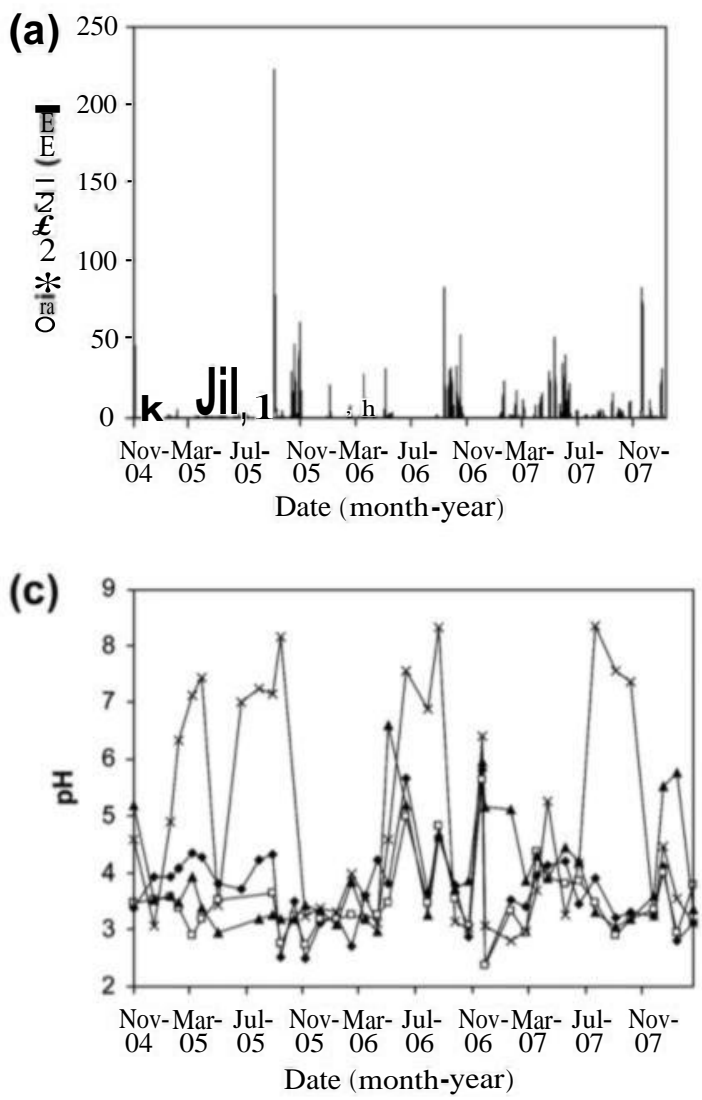

a step size of $0.03^{\circ}$. Samples were analyzed in continuous mode using a Panalytical X'Pert Pro MPD diffractometer equipped with an $\mathrm{X}^{\prime}$ Celerator detector, counting $2 \mathrm{~h}$ per sample.

\section{Results}

\subsection{Monthly variations in water chemistry}

The variations in the main physicochemical parameters (rainfall, $\mathrm{pH}, \mathrm{DO}$, temperature (T), and $\mathrm{SO}_{4}^{2-}$ ) along Reigous Creek are presented in Fig. 2. The mean annual rainfall in the Reigous basin during the study period was $660 \mathrm{~mm}$. The distribution of monthly rainfall was typical of the Mediterranean climate, including long drought periods in summer and intense rainfall events especially in autumn (September to November) and to a lesser extent in
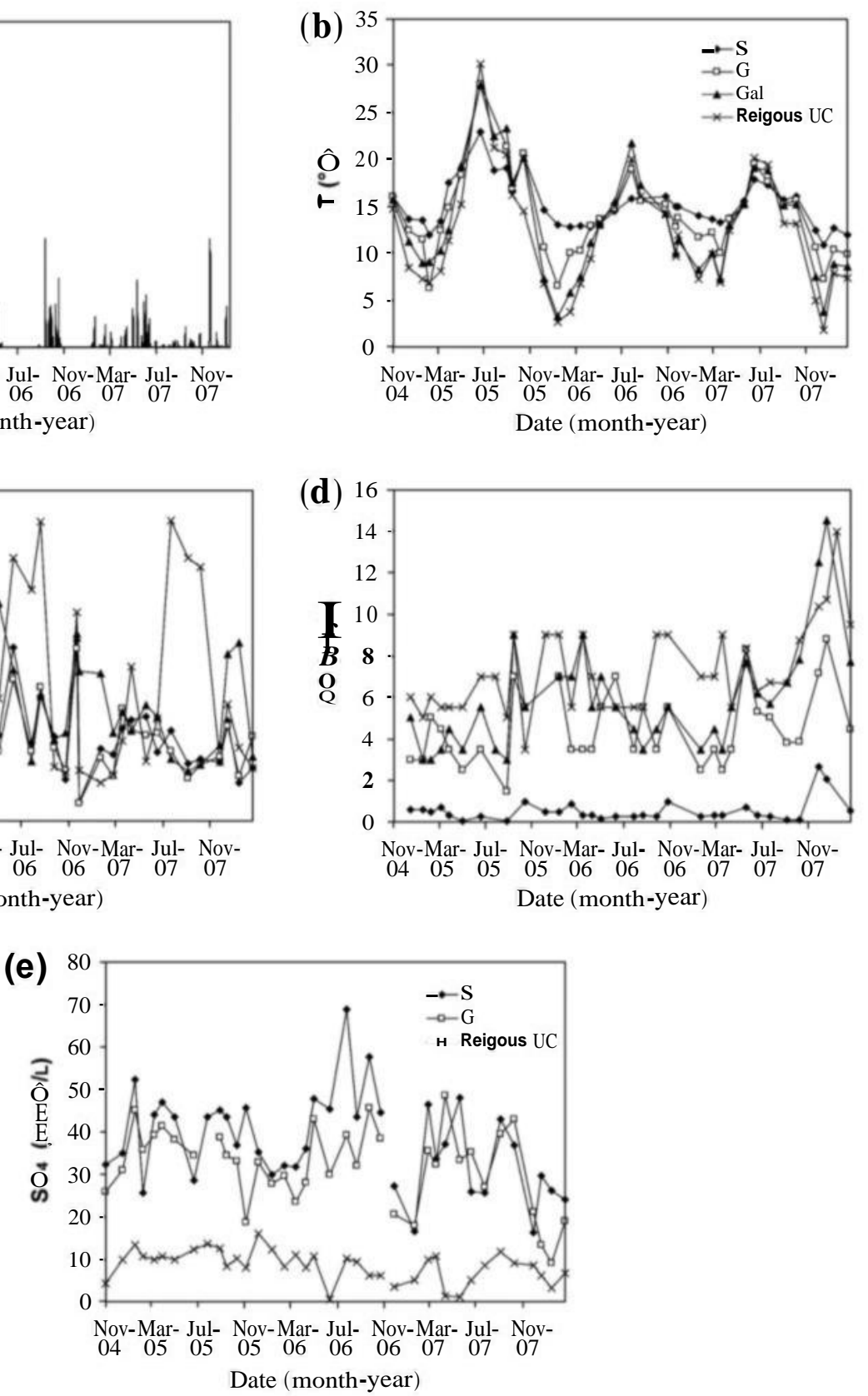

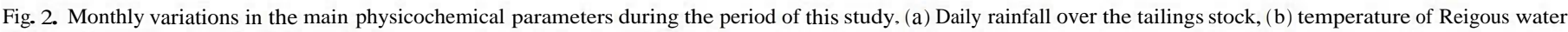
(T), (c) $\mathrm{pH}$. (d) dissolved 02 (DO), and (e) concentrations of dissolved SO( ${ }^{-}$. 
spring (May). The temperature of the water at the source of the Reigous varied slightly $\left(15.1 \pm 2.6{ }^{\circ} \mathrm{C}\right)$. In Reigous Creek, the water temperature is affected by the air temperature resulting in a larger range of values. Except at the Reigous UC station, the Reigous water was generally acidic with $\mathrm{pH}$ values between 2.39 (station $\mathrm{G}$ ) and $\mathrm{pH} 6.60$ (station Gal). The variance of $\mathrm{pH}$ values was less than $25 \%$. At Reigous UC station, greater $\mathrm{pH}$ variations were observed, with $\mathrm{pH}$ values ranging from 2.82 to 8.35 , the highest values being encountered during the driest months. This pattern of $\mathrm{pH}$ variations attests to the negligible contribution of AMD during the dry period due to evaporation between the source and the Reigous UC station. It also indicates that the input of water is not contaminated by AMD. Dissolved 02 concentrations in the water at the Reigous source ranged from below detection limit $\left(0.1 \mathrm{mg} \mathrm{L}^{-1}\right)$ to $2.7 \mathrm{mg} \mathrm{L}^{-}$, the highest values being observed after rainfall events. Dissolved 02 increased sharply between stations S and G, indicating rapid oxygenation occurs in this creek segment.

Sulfate concentrations ranged from 10 to $70 \mathrm{mmol} \mathrm{L}^{-1}$ in the water at the source. Concentrations decreased gradually along
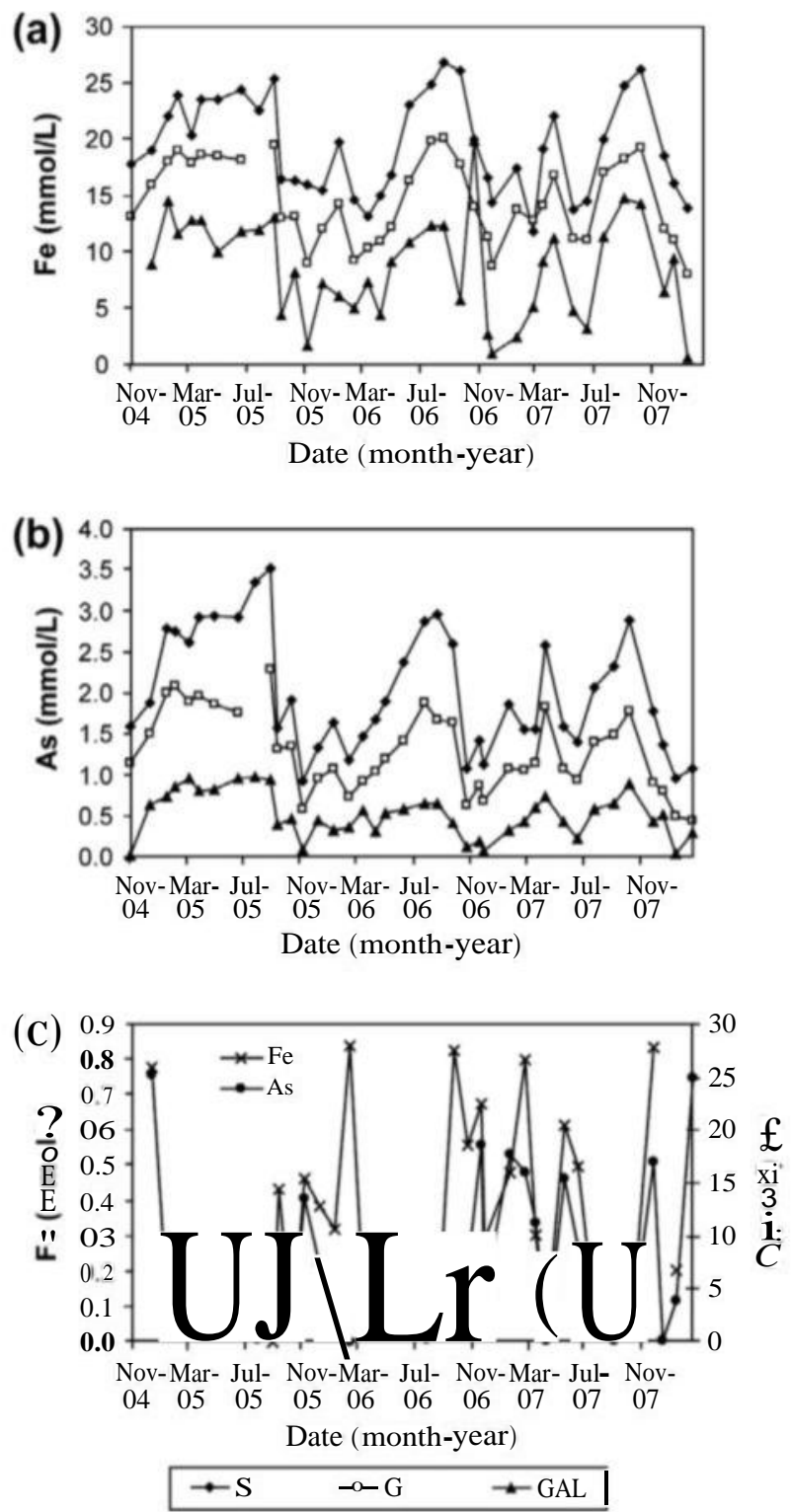

Fig. 3. Monthly variations in As and Fe concentrations in Reigous Creek (a) total dissolved Fe, (b) total concentrations of dissolved As, (c) total concentrations of dissolved Fe and As at Reigous UC station.
Reigous Creek. At the Reigous UC station, they ranged between 1 and $16 \mathrm{mmol} \mathrm{L}^{-1}$. Seasonal variations were also observed with an increase in concentrations during the driest months. The variations in dissolved $\mathrm{Fe}$ and As in Reigous Creek are shown in Fig. 3. The variations in the concentrations of the two elements confirm those reported by Casiot et al. (2003). Dissolved Fe concentrations ranged from 12 to $25 \mathrm{mmol} \mathrm{Ir}^{1}$ in water at the source. Concentrations decreased from the source to the Reigous UC station where Fe concentrations were always below $0.84 \mathrm{mmol} \mathrm{L}^{-1}$. Iron concentrations generally increased during the driest months and decreased as a result of intense rainfall events except at the Reigous UC station where the reverse pattern was observed (i.e. lower values during the driest months) due to resurgences of unpolluted water from the Amous River in the Reigous Creek just before the confluence. In the water at the source, the concentrations of dissolved As ranged from 0.9 to $3.5 \mathrm{mmol} \mathrm{L}{ }^{-1}$. Arsenic concentrations decreased with distance from the source to values below $25 \mathrm{pmol} \mathrm{L}^{-1}$ at the Reigous UC station. Generally higher concentrations were observed during the driest months except at Reigous UC station, which displayed higher concentrations during the wet season. Over the year, the proportion of As removed from water was almost constant around 30\%, whatever the flow rate or the concentrations of $\mathrm{Fe}$ or As in the dissolved phase. The proportion of $\mathrm{Fe}(111)$ was generally negligible in Reigous Creek except at the Reigous UC station where it was 30\% (Fig. 4). In the first $150 \mathrm{~m}$ of the creek, the mean proportion of $\mathrm{As}(\mathrm{V})$ reached $40 \%$. Further downstream the proportion of $\mathrm{As}(\mathrm{V})$ increased to reach $80 \%$ at the Reigous UC station.

\subsection{Solid phase mineralogy and chemistry}

Results of XRD analyses are presented in Fig. 5. At stations S and $\mathrm{G}$, they indicate the presence of generally amorphous precipitates probably made of $\mathrm{Fe}(\mathrm{HI})-\mathrm{As}(\mathrm{V})$ phases as previously found by Morin et al. (2003) except in July at station S where very small quantities of tooeleite were encountered. The structure of this Fe(III)As(III) mineral has been described by Morin et al. (2007). At station $\mathrm{E}$, the data revealed the presence of significant proportions of tooeleite throughout the year. At the same stations, dry sediments were generally more crystalline than fresh sediments suggesting that ageing and/or dehydration of precipitates favor the formation of tooeleite. At the Gal and Reigous UC stations, the presence of schwertmannite was observed, in agreement with the results of Casiot et al. (2005).

The mean chemical composition of precipitates is given in Table 1. The mean proportion of As ranged between $2 \%$ and $20 \%$, and that of $\mathrm{Fe}$ between $13 \%$ and 35\%. Arsenic/Fe molar ratios at upstream stations ( $\mathrm{S}, \mathrm{G}$ and $\mathrm{E})$ varied from 0.20 to 0.94 with an average of 0.61 . The data did not indicate any influence of phase crystallinity

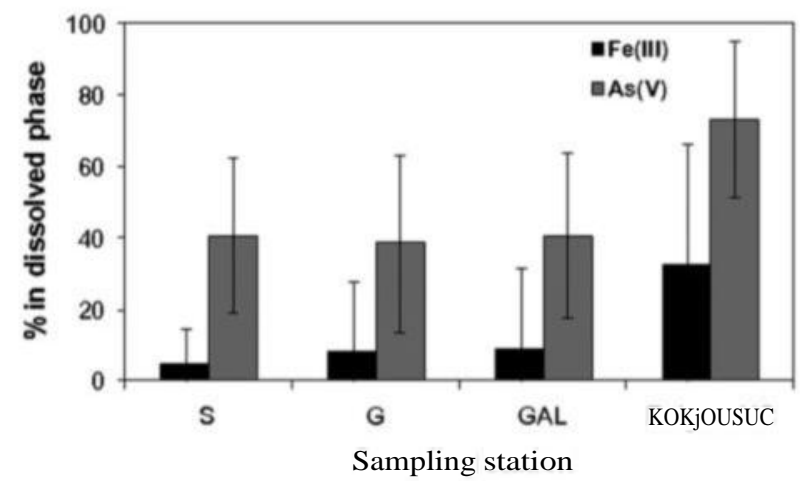

Fig. 4. Mean values and standard deviations of monthly variations in the proportion of (a) $\mathrm{Fe}(111)$ and (b) As(V) in Reigous Creek. 

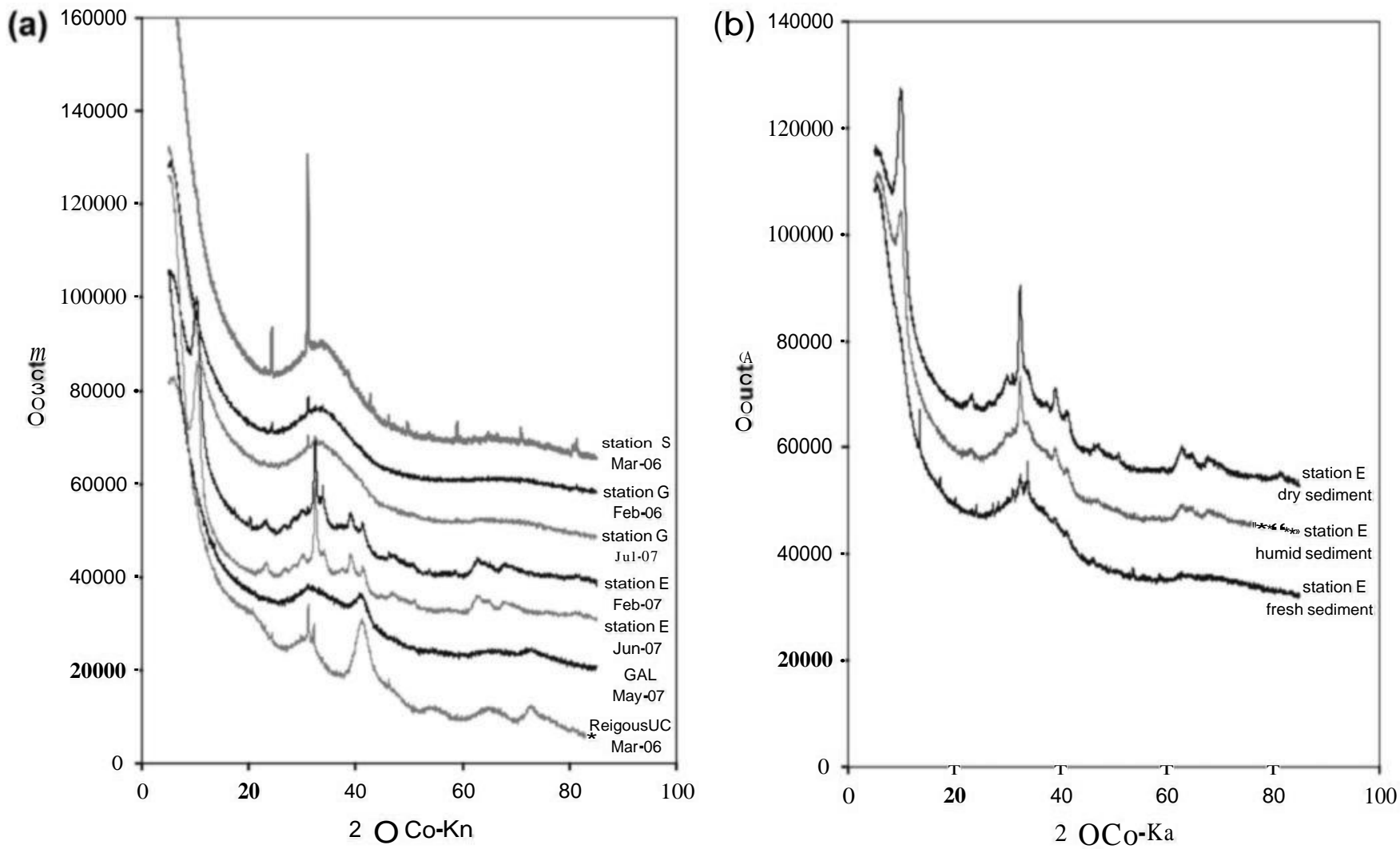

Fig. 5. XRD spectrum of Reigous Creek precipitates.

Table 1

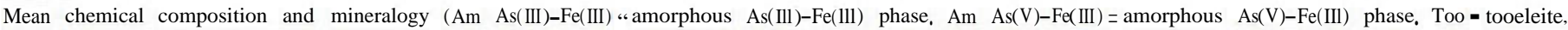
$\mathrm{Schw}=$ schwertmannite, $\mathrm{Fh}=$ ferrihydrite $)$ of different precipitates recovered in the bed of the Reigous Creek.

\begin{tabular}{|c|c|c|c|c|c|c|c|c|c|c|c|}
\hline \multirow[t]{2}{*}{ Sampling stations } & \multirow[t]{2}{*}{ Facies } & \multicolumn{3}{|l|}{$\%$ As } & \multicolumn{3}{|l|}{$\% \mathrm{Fe}$} & \multicolumn{3}{|l|}{$\mathrm{As} / \mathrm{Fe}$} & \multirow[t]{2}{*}{ Mineralogy } \\
\hline & & Mean & Min & Max & Mean & $\mathrm{mm}$ & Max & Mean & $\mathrm{mm}$ & $\operatorname{Max}$ & \\
\hline \multirow[t]{3}{*}{$S$} & Fresh sediments & 15 & 12 & 19 & 23 & 20 & 30 & 0.58 & 0.54 & 0.69 & \multirow[t]{3}{*}{$\operatorname{Am~As(111)-Fe(1ll)/Am~As(V)-Fe(1ll)~}$} \\
\hline & Laminated concretions & 16 & 12 & 19 & 28 & 24 & 33 & 0.62 & 0.49 & 0.71 & \\
\hline & Dry sediments & 6 & 4 & 7 & 12.6 & & & 0.25 & 0.20 & 0.34 & \\
\hline \multirow[t]{3}{*}{ E } & Fresh sediments & 15 & 13 & 17 & 26 & 21 & 32 & 0.57 & 0.39 & 0.71 & Too \\
\hline & Laminated concretions & 15 & 11 & 23 & 27 & 24 & 33 & 0.56 & 0.43 & 0.82 & Too \\
\hline & Dry sediments & 17 & 11 & 22 & 22 & 16 & 29 & 0.74 & 0.45 & 0.90 & Too \\
\hline \multirow[t]{2}{*}{ G } & Fresh sediments & 15 & 11 & 21 & 21 & 13 & 29 & 0.74 & 0.60 & 0.92 & $\operatorname{Am~As}(\mathrm{V})-\mathrm{Fe}(111)$ \\
\hline & Dry sediments & 20 & 14 & 23 & 23 & 18 & 27 & 0.83 & 0.70 & 0.94 & Too \\
\hline GAL & Fresh sediments & 12 & 7 & 18 & 31 & 20 & 37 & 0.35 & 0.18 & 0.39 & Schw \\
\hline Reigous UC & Fresh sediments & 2 & 0 & 3 & 35 & 24 & 43 & 0.05 & 0.02 & 0.10 & Schw/Fh \\
\hline
\end{tabular}

and/or the spéciation of As on the As/Fe ratio. Between stations $\mathrm{S}$ and $\mathrm{G}$, the precipitates displayed higher As/Fe ratios than the As/ Fe ratio calculated using the quantities of As and Fe that disappeared from the aqueous phase, which were between 0.045 and 0.14 (Table 1). One explanation for this discrepancy could be related to granulometric sorting of phases with different As/Fe ratios during sedimentation. At the Gal and Reigous UC stations, the As/ $\mathrm{Fe}$ ratios were generally lower than those upstream.

\subsection{Diel variations in the main physicochemical parameters and As and Fe concentrations}

The variations in the main physicochemical characteristics of water over a 36-h period and their relationship with light intensity were studied in Reigous Creek. Water-quality parameters such as $\mathrm{pH}$, redox potential (Eh), conductivity (/), dissolved 02 (DO), light intensity ( $\mathrm{Li}$ ) and temperature $(\mathrm{T})$ were measured in the field. Dissolved 02, T and Li data are reported in Fig. 6a. Diel variations in As and Fe concentrations were also evidenced in Reigous Creek, with an increase in $\mathrm{Fe}$ and As concentrations during the day (maximum at $12 \mathrm{am}$ ) and a decrease during the evening and the night (Fig. 6b). The cyclical trend reflects the influence of the daily light cycle. Variations in $\mathrm{Fe}$ and As concentrations are positively correlated with light intensity. The maximum difference in the dissolved concentrations of both elements between $12 \mathrm{am}$ and $12 \mathrm{pm}$ was around $10 \%\left(1.1 \mathrm{mmol} \mathrm{L}^{-1}\right.$ and $0.16 \mathrm{mmol} \mathrm{L}^{-1}$ for $\mathrm{Fe}$ and As, respectively). Given that $\mathrm{Fe}$ is mainly in the reduced form, fluctuations in the $\mathrm{Fe}(\mathrm{II}) /$ Fetot ratio values are not significant and it can be 

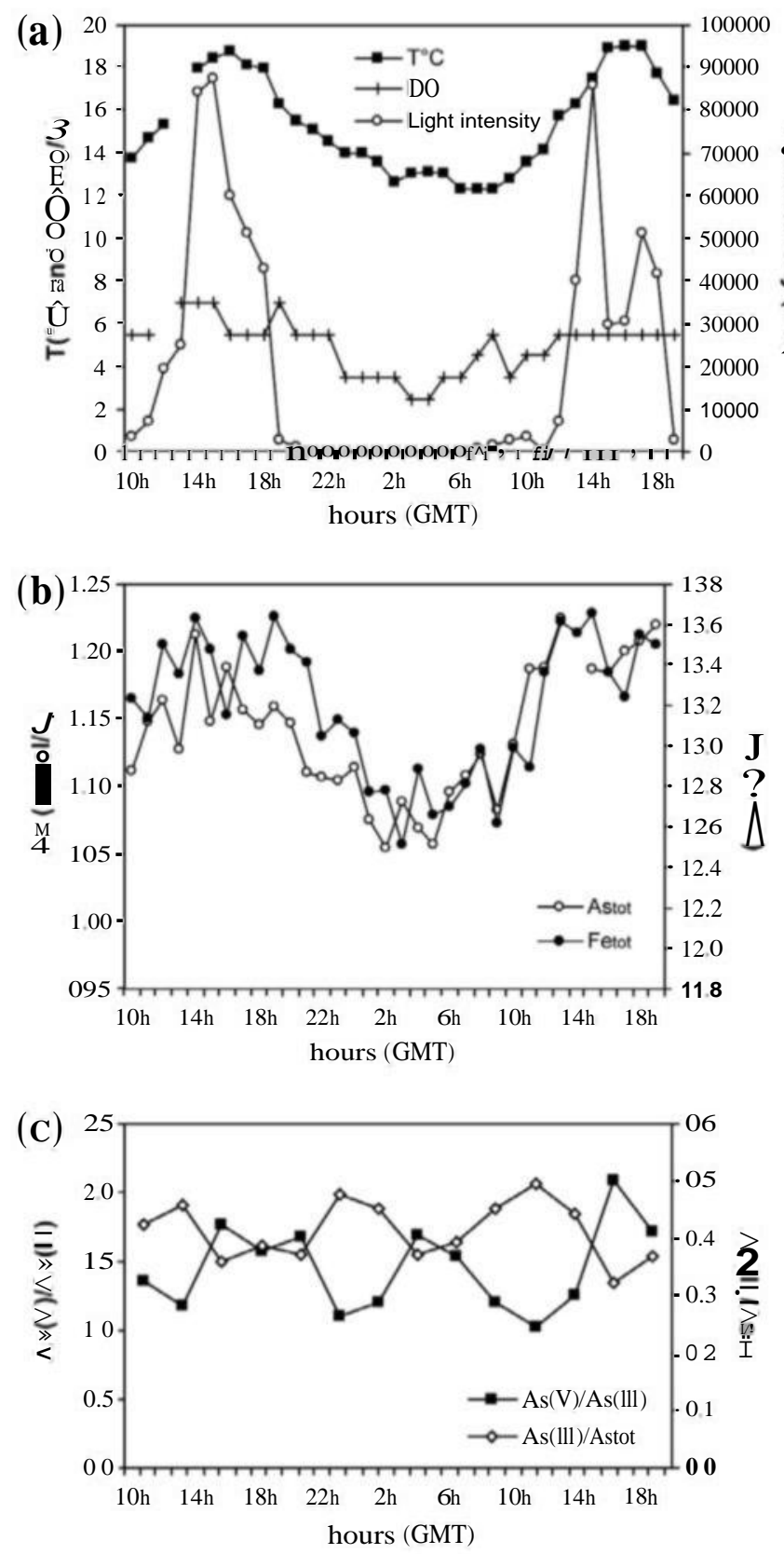

Fig. 6. Diel variations at station G (May 9-10, 2007) in (a) light intensity (Li), dissolved 02 (IX) and temperature (T); (b) dissolved Fe and As; (c) As(III)/Astol and $\mathrm{As}(\mathrm{V}) / \mathrm{As}(\mathrm{III})$.

assumed that variations in total Fe concentrations reflect $\mathrm{Fe}(\mathrm{II})$ variations. Between $30 \%$ and $50 \%$ of As is in the reduced form, and As(III) is negatively correlated with total Fe, while total As concentrations vary between 370 and $590 \mathrm{pmol} \mathrm{L}^{-1}$ which represents $35 \%$ of variations. Interestingly, maximum $\mathrm{As}(111) / \mathrm{As}_{\text {, }}$, ratios were observed between $2 \mathrm{pm}$ and $4 \mathrm{pm}$ (Fig. 6c).

\section{Discussion}

\subsection{Coprecipitation of $\mathrm{Fe}$ and As}

In the first $40 \mathrm{~m}$ of the creek, monitoring confirmed previous results obtained during a shorter observation period, which showed intense decrease in the concentrations of dissolved As and $\mathrm{Fe}$ with increasing distance from the source. In this section of the creek, which receives negligible quantities of water from other sources, this decrease is due to Fe oxidation and removal of As by coprecipitation with Fe oxides. Flowever unlike previous observations, results of the present study showed that the percentage of As removed from solution was constant at around 30\% and independent of the initial concentration of dissolved As or Fe.

The saturation indices reported as a function of $\mathrm{pH}$ are shown in Fig. 7. These saturation indices have been calculated using the chemical composition of water emerging at the Reigous spring according to the following formula:

$\mathrm{SI}=\log (\mathrm{IAP})-\log (\mathrm{IC})$

where SI corresponds to saturation indices, IAP is the ionic activity product and $K$ is the equilibrium constant of the mineral phase.

To make a more equitable comparison, the saturation indices for all Fe-containing minerals have been adjusted to one Fe atom per formula unit (Gammons et al., 2008). For the calculations, it was hypothesized that available $\mathrm{Fe}(111)$ for precipitation within the first $40 \mathrm{~m}$ corresponded to total Fe precipitated along this distance. Based on the equilibrium constants given by different authors (Bigham et al,, 1996a; Regenspurg, 2002; Yu et al,, 2002; Majzlan et al,, 2004; Parmentier, 2006), Reigous Creek is supersaturated with respect to all Fe hydroxides precipitates regardless of the schwertmannite solubility constant used (Bigham et al, 1996a; Yu et al,, 1999, 2002; Majzlan et al., 2004). According to these calculations, jarosite precipitation would be expected to occur below $\mathrm{pH} 4$ whereas schwertmannite should form at $\mathrm{pH}>4$ as generally observed in AMD (Bigham et al,, 1996a; Regenspurg et ai,, 2004; Sanchez-Espana et al., 2007). However, the field observations did not conform to these calculations. In agreement with the previous observations of Morin et al. (2003), the study showed the precipitation of amorphous $\mathrm{As}(\mathrm{V})-\mathrm{Fe}(\mathrm{III})$ or $\mathrm{As}(\mathrm{III})-\mathrm{Fe}(\mathrm{lll})$ solid phases and tooeleite in the first $40 \mathrm{~m}$ downstream from the source of Reigous Creek. This may be explained by the fact that thermodynamic predictions do not take into account kinetic factors (such as $\mathrm{Fe}(\mathrm{II})$ oxidation and subsequent of $\mathrm{Fe}(111)$ precipitation) and by the presence of high quantities of As, which prevent the formation of classical crystalline phases, as suggested by Langmuir et al. (2006) and Carlson et al. (2002) for schwertmannite. Concerning schwertmannite, its precipitation should occur when As concentra-

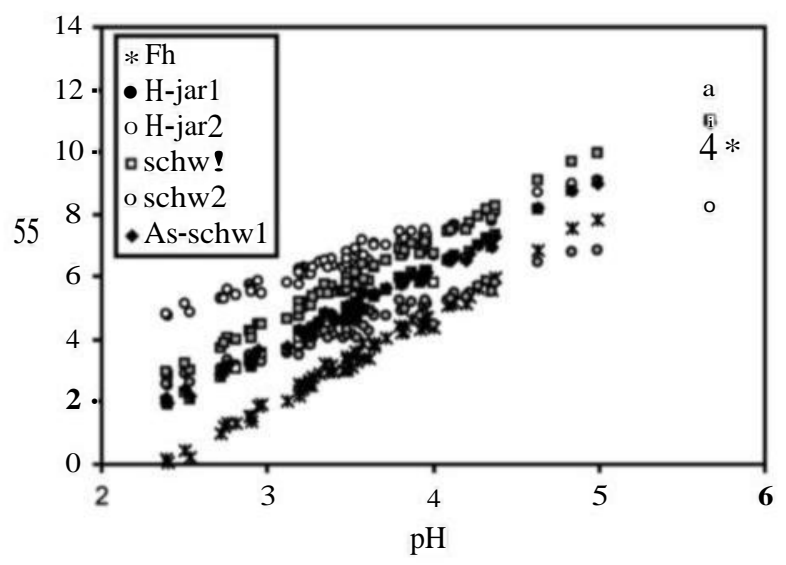

Fig. 7. Saturation indices of the main Fe-minerals as a function of $\mathrm{pH}$ in the water at the source of Reigous Creek. The saturation indices for all Fe-containing minerals were adjusted to one $\mathrm{Fe}$ atom per formula unit (Gammons et al., 2008). The following stability constants were used: H-jarosite $1, \log K *-5.39$ (Sarmiento, 2007); H-jarosite 2, $\log K=12.1$ (Sarmiento, 2007); ferrihydrite, $\log K=4.89$ (Bigham et al., 1996a); schwertmannite $1, \log K=18$ (Bigham et al., 1996b); schwertmannite 2, $\operatorname{logic} * 10.5$ (Yu et al, 1999); arsenical schwertmannite, $\log K=13.5$ (Regenspurg. 2002). 
tion is low compared to Fe(III) and this is not the case in Reigous Creek close to the spring. Moreover, although thermodynamic data for amorphous phases and tooeleite are not available, both field observations and laboratory experiments have shown that the formation of this mineral is clearly linked to bacterial activity and kinetic aspects. It is favoured by slow reactions and flow rates (Morin et al,, 2007; Egal et al., 2009). Its crystallinity is improved by ageing and subsequent dehydration of a primary mineral phase that seems to be an amorphous $\mathrm{As}(\mathrm{III})-\mathrm{Fe}(111)$ oxide. Indeed, bacteria that mediate redox reactions involving $\mathrm{As}$ and $\mathrm{Fe}$ in the system could also play a major role in determining the nature of the solid phase, as demonstrated by Duquesne et al. (2003), however, preliminary results on bacterial strain evolution throughout the year in Reigous Creek did not allow an explanation of mineralogical variations observed in the field.

After $40 \mathrm{~m}$, Reigous Creek receives water from seepage and small tributaries, which are not influenced by AMD. This process results in the dilution of As. In contrast to the findings obtained in the first $40 \mathrm{~m}$ of the creek, the formation of more common As-Fe phases such as As-rich schwertmannite and ferrihydrite was observed in this reach. This is consistent with the low concentrations of As that do not prevent formation of crystalline mineralogical phases as described above. The succession of Fe oxides (schwertmmanite and ferrihydrite) is consistent with the increase in $\mathrm{pH}$ values along the stream from spring to confluence.

\subsection{Iron oxide photoreduction and release of arsenic}

At station G, concomitant diel variations in As and Fe in solution were observed. An increase in concentrations characterized by a maximum at 12 am was obseived and is likely due to photoreduction of Fe-oxide phases which releases $\mathrm{Fe}$ (II) as reported elsewhere for acidic waters (Collienne, 1983; Sullivan et al,, 1998; McKnight et al., 2001; Butler and Seitz, 2006; Gammons et al,, 2008). Iron photochemical reduction is a chemical process whereby photons, generally in the wavelength range of 360-450 nm (ultraviolet radiation) or slightly longer in very acidic waters (Diez Ercilla et al., 2009), are absorbed by dissolved Fe(III) species or freshly precipitated $\mathrm{Fe}(\mathrm{III})$ oxyhydroxide surfaces. At night the decrease in $\mathrm{Fe}$ and As concentrations is explained by oxidation of $\mathrm{Fe}(11)$ into $\mathrm{Fe}(111)$ and subsequent precipitation of Fe oxides combined with adsorption or coprecipitation of As. During the day, the photoreduction competes with oxidation and leads to the dissolution of Fe precipitates and the release of the sorbed As.

The maximum $\mathrm{As}(\mathrm{V}) / \mathrm{As}(\mathrm{III})$ ratio (Fig. 6c) observed during the decreasing phase of As concentrations between 2 and 4 pm suggests that $\mathrm{As}(111)$ has more rapid recombination (coprecipitation or adsorption) kinetics with Fe oxides than $\mathrm{As}(\mathrm{V})$. This corroborates the results of Raven et al. (1998) who showed more rapid adsorption of $\mathrm{As}(111)$ on ferrihydrite in acidic $(\mathrm{pH} 4.6)$ water with a high (As/Fe molar ratio 1.18) initial addition of As. Moreover, the concomitant increase of As(IIl)/Asto, ratio and decrease of As(V)/As(III) ratio (Fig. 6c) in the dissolved phase during the increase in light intensity may be related to $\mathrm{As}(\mathrm{III})$ release from the solid phase due to the reduction of $\mathrm{As}(\mathrm{V})$ released into solution consequent to desorption from Fe hydroxides. Indeed, reduction of arsenate to arsenite may occur after $\mathrm{Fe}(111)$ reduction (Islam et al., 2004; Pedersen, 2006). The decrease in As( III)/Astot molar ratio simultaneously with light intensity may be explained by both a decrease in photoreduction intensity and $\mathrm{As}(\mathrm{V})$ reduction. During the first hours of night, As(III)/As, ot molar ratio shows an increase simultaneously with a decrease in As concentrations that may be related to greater precipitation or adsorption of $\mathrm{As}(\mathrm{V})$. Then a balance with oxidation of As and subsequent decrease in As(111) concentrations related to precipitation of As-rich $\mathrm{Fe}$ oxides is evidenced in the dissolved concentrations. Mineralogical analyses have previously

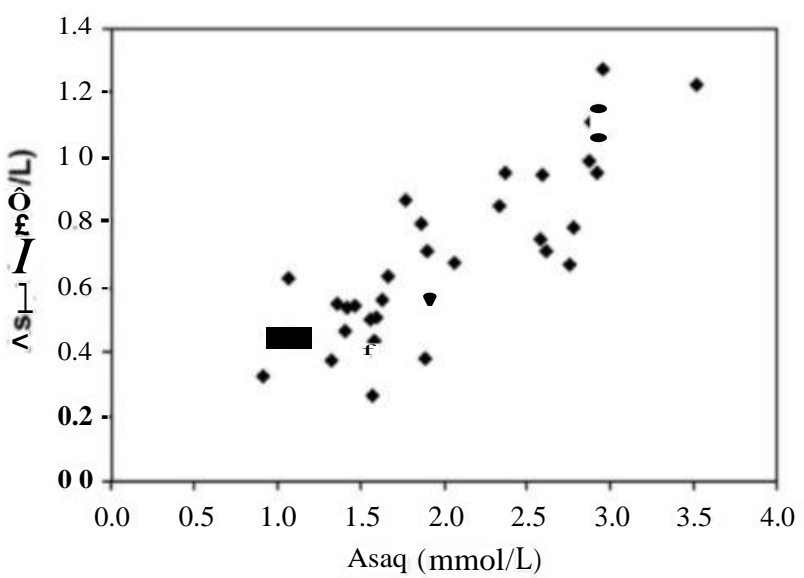

Fig. 8. Quantity of As removed from solution between stations S and G (ASpp, ) as a function of the total concentration of dissolved As at station S (Asaq).

demonstrated that Fe precipitates at the station $\mathrm{G}$ are mainly constituted of an $\mathrm{As}(\mathrm{V})-\mathrm{Fe}(\mathrm{III})$ amorphous phase (Morin et al, 2003) which is consistent with $\mathrm{As}(\mathrm{V})$ precipitation and release. Moreover, As/Fe ratios are about $0.086 \pm 0.003$ and cyclical variations of this ratio emerge with slightly lower values during the night and an increase during daytime. Such an increase in As/Fe ratio means that more As is released into solution than Fe.

\subsection{Global removal of iron and arsenic}

Despite diel variations leading to the release of $\mathrm{Fe}$ and As into solution, a consequence of photoreduction, natural removal of pollutants occurs in Reigous Creek, on a greater scale. The quantity of As removed per liter of water in the first $40 \mathrm{~m}$ of Reigous Creek was calculated by the difference between the As concentrations at stations $\mathrm{S}$ and $\mathrm{G}$. This quantity is proportional to the As concentration in spring water (Fig. 8). The corresponding percentage of As removed from solution is constant (around 30\%) over the year. This result, which was based on a longer observation period, does not corroborate the results obtained from a 1-year monitoring study carried out in 2001 (Casiot et al., 2003), where a greater proportion of As was removed in the first $40 \mathrm{~m}$ of Reigous creek in winter than in summer.

The mean rate of $\mathrm{Fe}(\mathrm{ll})$ oxidation in the first $40 \mathrm{~m}$ between stations $\mathrm{S}$ and $\mathrm{G}$ was estimated from the following equation:

rox $=\mathrm{A}[\mathrm{Fe}(\mathrm{II})] / \mathrm{At}=\left([\mathrm{Fe}(\mathrm{II})]_{\mathrm{S}}-[\mathrm{Fe}(\mathrm{II})]_{\mathrm{C}}\right) / \mathrm{t}$

where rox is the oxidation rate and $t$ is the travel time of the water $(1080 \mathrm{~s})$ between the two stations. The values found for rox (3.8 $\times 10^{-6} \mathrm{~mol} \mathrm{~L}^{-1} \mathrm{~s}^{-1}$ on July 2008) are in good agreement with the value $\left(8 \times 10^{-7} \mathrm{~mol} \mathrm{~L}^{-1} \mathrm{~s}^{-1}\right)$ reported by Sanchez-Espana et al. (2007) in a similar environment.

The precipitation rate of $\mathrm{Fe}$ (Ill) was identical to the $\mathrm{Fe}(\mathrm{II})$ oxidation rate since there was no build-up of $\mathrm{Fe}(\mathrm{III})$ in solution. Using a mean discharge at the source of $0.6 \mathrm{~L} \mathrm{~s}^{-} \backslash$ the corresponding quantity of $\mathrm{Fe}$ precipitated was $4 \mathrm{~kg} \mathrm{a}^{-1}$. The mean rate of As removal between the two stations calculated in the same manner was $0.55 \times 10^{-6} \mathrm{~mol} \mathrm{~L}^{-1} \mathrm{~s}^{-1}$ yielding the quantity of As removed, $0.8 \mathrm{kga}^{-1}$.

Between the Gal and Reigous UC stations, dilution processes added to coprecipitation contribute to a further decrease in the dissolved concentrations of As. At Reigous UC station, the dissolved As concentration was between $0.4 \%$ and $2.3 \%$ of that measured at the source of Reigous Creek. 


\section{Conclusions}

Monthly monitoring of both As and Fe concentrations and the main physicochemical parameters in Reigous Creek was done over 4 years. Reigous creek drains the tailings stock of the former $\mathrm{Pb}-\mathrm{Zn}$ mine of Carnoulès. The monitoring found an increase in As concentration in the AMD source occurred during the dry season.

Over the first $40 \mathrm{~m}$ of the creek, monitoring confirmed previous results obtained during a shorter observation period, which showed intense removal of As by coprecipitation with Fe oxides. However unlike previous observations, the results of the present study showed that the percentage of As removed from solution was constant at around 30\%. The corresponding rate of As removal was $3.58 \times 10^{-7} \mathrm{~mol} \mathrm{~L}^{-1} \mathrm{~s}^{-1}$.

The As-Fe rich precipitates that are deposited in the bed of this section of Reigous Creek consist of tooeleite, As(III)-Fe(III) and/or amorphous $\mathrm{As}(\mathrm{V})-\mathrm{Fe}(\mathrm{III})$ phases. Seasonal variations in sediments were observed with the appearance of tooeleite during the coldest months. Laminated concretions were mainly made up of this tooeleite whatever the period of the year.

Diel cycles of dissolved As and Fe concentrations were linked to photoreduction of Fe oxides. Fluctuations in dissolved As concentrations between midday and night were about $10 \%$.

After $40 \mathrm{~m}$, the combination of both dilution and adsorption/ coprecipitation processes led to a further decrease in As concentrations. The formation of more conventional Fe-oxide phases such as schwertmannite and ferrihydrite was observed. Upstream from the confluence with the Amous River the concentrations were between $0.4 \%$ and $2.4 \%$ of those observed at the source of Reigous Creek.

This study confirmed previous studies and showed that As undergoes significant natural attenuation in AMD impacted water. Nevertheless a significant quantity of highly contaminated sediment was produced and transported downstream during floods.

\section{Acknowledgements}

This study benefited from the financial support of the INSU through the ECODYN and EC2CO programmes and of the ANR Program (Number BLAN07-1_184878). The publication is a contribution of the OSU-OREME.

\section{References}

Banerjee, D., Amy, G.L., Prevost, M., Nour, S., Jekel, M., Gallagher, P.M., Blumenschein, C.D., 2008. Kinetic and thermodynamic aspects of adsorption of arsenic onto granular ferric hydroxide (GFH). Water Res. 42, 3371-3378.

Bednar, A.J., Garbarino, J.R., Ranville, J.F., Wildeman, T.R., 2002. Preserving the distribution of inorganic arsenic species in groundwater and acid mine drainage samples. Environ. Sci. Technol. 36, 2213-2218.

Bigham, J.M., Schwertmann, U., Pfab, G., 1996a. Influence of pH on mineral speciation in a bioreactor simulating acid mine drainage. Appl. Geochem. 11, 845-849.

Bigham, J.M., Schwertmann, U., Traina, S.J., Winland, R.L., Wolf, M., 1996b. Schwertmannite and the chemical modeling of iron in acid sulfate waters. Geochim. Cosmochim. Acta 60, 2111-2121.

Bruneel, O., Personne, J.-C., Casio, C., Leblanc, M., Elbaz-Poulichet, F., Mahler, B.J., Le Fleche, A., Grimont, P.A.D., 2003. Mediation of arsenic oxidation by Thiomonas sp. in acid-mine drainage (Carnoulès, France). J. Appl. Microbiol. 95, 492-499.

Bruneel, O., Duran, R., Koffi, K., Casiot, C., Fourçans, A., Elbaz-Poulichet, F., Personné, J.-C., 2005. Microbial diversity in a Pyrite-rich tailings impoundment (Carnoulès, France). Geomicrobiol. J. 22, 249-257.

Butler, I.B., Seitz, J.C., 2006. Apparent seasonal variations in iron photoreduction in acidic discharge from a former pyrite mine, Oakland. Calif. Appl. Geochem. 21, 1109-1122.

Carlson, L., Bigham, J.M., Schwertmann, U., Kyek, A., Wagner, F., 2002. Scavenging of As from acid mine drainage by schwertmannite and ferrihydrite: a comparison with synthetic analogues. Environ. Sci. Technol. 36, 1712-1719.

Casiot, C., Morin, G., Juillot, F., Bruneel, O., Personné, J.-C., Leblanc, M., Duquesne, K., Bonnefoy, V., Elbaz-Poulichet, F., 2003. Bacterial immobilization and oxidation of arsenic in acid mine drainage (Carnoul"es creek, France). Water Res. 37, 2929-2936.
Casiot, C., Lebrun, S., Morin, G., Bruneel, O., Personné, J.-C., Elbaz-Poulichet, F., 2005. Sorption and redox processes controlling arsenic fate and transport in a stream impacted by acid mine drainage. Sci. Total Environ. 347, 122-130.

Collienne, R., 1983. Photoreduction of iron in the epilimnion of acidic lakes. Limnol. Oceanogr. 28, 83-100.

Diez Ercilla, M., López Pamo, E., Sánchez España, J., 2009. Photoreduction of Fe(III) in the acidic mine pit lake of San Telmo (Iberian Pyrite Belt): field and experimental work. Aquat. Geochem. 15, 391-419.

Duquesne, K., Lebrun, S., Casiot, C., Bruneel, O., Personné, J.-C., Leblanc, M., ElbazPoulichet, F., Morin, G., Bonnefoy, V., 2003. Immobilization of arsenite and ferric iron by Acidithiobacillus ferrooxidans and its relevance to acid mine drainage. Appl. Environ. Microbiol. 60, 6165-6173.

Dzombak, D.A., Morel, F.M., 1990. Surface Complexation Modeling: Hydrous Ferric Oxide. John Wiley and Sons, New York.

Egal, M., Casiot, C., Morin, G., Parmentier, M., Bruneel, O., Lebrun, S., Elbaz-Poulichet F., 2009. Kinetic control on the formation of tooeleite, schwertmannite and jarosite by Acidithiobacillus ferrooxidans strains in an As(III)-rich acid mine water. Chem. Geol. 265, 432-441.

Fukushi, K., Sato, T., Yanase, N., 2003. Solid-solution reactions in As(V) sorption by schwertmannite. Environ. Sci. Technol. 37, 3581-3586.

Fukushi, K., Sato, T., Yanase, N., Minato, J., Yamada, H., 2004. Arsenate sorption on schwertmannite. Am. Mineral. 89, 1728-1734.

Fuller, C.C., Davis, J.A., 1989. Influence of coupling of sorption and photosynthetic processes on trace element cycles in natural waters. Nature 340, 52-54.

Gammons, C.H., Nimick, D.A., Parker, S.R., Snyder, D.M., McCleskey, R.B., Amils, R., Poulson, S.R., 2008. Photoreduction fuels biogeochemical cycling of iron in Spain's acid rivers. Chem. Geol. 252, 202-213.

Islam, F.S., Gault, A.G., Boothman, C., Polya, D.A., Charnock, J.M., Chatterjee, D., Lloyd, J.R., 2004. Role of metal-reducing bacteria in arsenic release from Bengal delta sediments. Nature 430, 68-71.

Jain, A., Raven, K.P., Loeppert, R.H., 1999. Arsenite and arsenate adsorption on ferrihydrite: surface charge reduction and Net OH-release stoichiometry. Environ. Sci. Technol. 33, 1179-1184.

Jönsson, J., Sherman, D.M., 2008. Sorption of As(III) and As(V) to siderite, green rust (fougerite) and magnetite: implications for arsenic release in anoxic groundwaters. Chem. Geol. 255, 173-181.

Karlsson, S., Hakansson, K., Ledin, A., Allard, B., 1995. Light induced changes of $\mathrm{Fe}(\mathrm{II}) / \mathrm{Fe}(\mathrm{III})$ and their implications for colloidal forms of $\mathrm{Al}, \mathrm{Mn}, \mathrm{Cu}, \mathrm{Zn}$ and $\mathrm{Cd}$ in an acidic lake polluted with mine waste effluents. J. Geochem. Explor. 52, 145159.

Koffi, K., Leblanc, M., Jourde, H., Casiot, C., Pistre, S., Gouze, P., Elbaz-Poulichet, F. 2003. Reverse oxidation zoning in mine tailings generating arsenic-rich acidic waters (Carnoulès, France). Mine Water Environ. 22, 7-14.

Langmuir, D., Mahoney, J., Rowson, J., 2006. Solubility products of amorphous ferric arsenate and crystalline scorodite $\left(\mathrm{FeAsO}_{4} \cdot 2 \mathrm{H}_{2} \mathrm{O}\right)$ and their application to arsenic behavior in buried mine tailings. Geochim. Cosmochim. Acta 70, 2942 2956

Leblanc, M., Achard, B., Ben Othman, D., Luck, J.M., 1996. Accumulation of arsenic from acidic mine waters by ferruginous bacterial accretions (stromatolites) Appl. Geochem. 11, 541-554.

Majzlan, J., Navrotsky, A., Schwertmann, U., 2004. Thermodynamics of iron oxides: part III. Enthalpies of formation and stability of ferrihydrite $\left(\mathrm{Fe}(\mathrm{OH})_{3}\right)$ schwertmannite $\left(\mathrm{FeO}(\mathrm{OH})_{3} / 4\left(\mathrm{SO}_{4}\right) 1 / 8\right)$, and $\varepsilon-\mathrm{Fe}_{2} \mathrm{O}_{3}$. Geochim. Cosmochim. Acta 68, 1049-1059.

Masue, Y., Loeppert, R.H., Kramer, T.A., 2007. Arsenate and arsenite adsorption and desorption behavior on coprecipitated aluminum: iron hydroxides. Environ. Sci. Technol. 41, 837-842.

McKnight, D.M., Kimball, B.A., Runkel, R.L., 2001. PH dependence of iron photoreduction in a rocky mountain stream affected by acid mine drainage. Hydrol. Process. 15, 1979-1992.

Morin, G., Juillot, F., Casiot, C., Bruneel, O., Personné, J.-C., Elbaz-Poulichet, F. Leblanc, M., Ildefonse, P., Calas, G., 2003. Bacterial formation of tooeleite and mixed Arsenic(III) or Arsenic(V)-Iron(III) gels in the carnoulès acid mine drainage, France. A XANES, XRD, and SEM study. Environ. Sci. Technol. 37, 1705-1712.

Morin, G., Rousse, G., Elkaim, E., 2007. Crystal structure of tooeleite Fe6 $\left(\mathrm{AsO}_{3}\right) 4 \mathrm{SO}_{4}(\mathrm{OH})_{4} \cdot 4 \mathrm{H}_{2} \mathrm{O}$, a new iron arsenite oxyhydroxysulfate mineral relevant to acid mine drainage. Am. Mineral. 92, 193-197.

Nimick, D.A., Cleasby, T.E., McCleskey, R.B., 2005. Seasonality of diel cycles of dissolved trace-metal concentrations in a rocky mountain stream. Environ Geol. 47, 603-614.

Parmentier, M., 2006. Développement d'un module microbiologique dédié à la modélisation hydrobiogéochimique et applications à la mobilité de l'arsenic Ecole des Mines de Paris.

Pedersen, H.D., 2006. The Transformation of Fe(III) Oxides Catalysed by $\mathrm{Fe}^{2+}$ and the Fate of Arsenate During Transformation and Reduction of Fe(III) Oxides. Technical Univ. Denmark, Copenhagen.

Pedersen, H.D., Postma, D., Jakobsen, R., 2006. Release of arsenic associated with the reduction and transformation of iron oxides. Geochim. Cosmochim. Acta 70, 4116-4129.

Raven, K.P., Jain, A., Loeppert, R.H., 1998. Arsenite and arsenate adsorption on ferrihydrite: kinetics, equilibrium, and adsorption envelopes. Environ. Sci. Technol. 32, 344-349.

Regenspurg, S., 2002. Characterisation of schwertmannite - geochemical interactions with arsenate and chromate and significance in sediments of 
lignite opencast lakes. Dissertation aus dem Lehrstuhl für Hydrologie der Fakultät für Chemie, Biologie und Geowissenschaften, der Univ. Bayreuth.

Regenspurg, S., Brand, A., Peiffer, S., 2004. Formation and stability of schwertmannite in acidic mining lakes. Geochim. Cosmochim. Acta 68, 1185-1197.

Rodier, J., Broutin, J.P., Chambon, P., Champsaur, H., Rodi, L., 1996. L'analyse de l'eau. Dunod, Paris.

Sanchez-España, J., Lopez-Pamo, E., Santofimia-Pastor, E., 2007. The oxidation of ferrous iron in acidic mine effluents from the Iberian Pyrite Belt (Odiel Basin, Huelva, Spain): field and laboratory rates. J. Geochem. Explor. 92, 120-132.

Sarmiento, A.M., 2007. Study of the pollution by acid mine drainage of surface wate in the basin of the Odiel River (SW Spain). Facultad de Ciencias Experimentales, Huelva (in Spanish).

Smedley, P.L., Kinniburgh, D.G., 2002. A review of the source, behaviour and distribution of arsenic in natural waters. Appl. Geochem. 17, 517-568.
Sullivan, L.A., Drever, J.I., McKnight, D.M., 1998. Diel variation in element concentrations, Peru Creek, Summit County. Colo. J. Geochem. Explor. 64, 141-145.

Tate, C.M., Broshears, R.E., McKnight, D.M., 1995. Phosphate dynamics in an acidic mountain stream: interactions involving algal uptake, sorption by iron oxide, and photoreduction. Limnol. Oceanogr. 40, 938-945.

Waychunas, G.A., Rea, B.A., Fuller, C.C., Davis, J.A., 1993. Surface chemistry of ferrihydrite: part 1. EXAFS studies of the geometry of coprecipitated and adsorbed arsenate. Geochim. Cosmochim. Acta 57, 2251-2269.

Yu, J.-Y., Heo, B., Choi, I.-K., Cho, J.-P., Chang, H.-W., 1999. Apparent solubilities of schwertmannite and ferrihydrite in natural stream waters polluted by mine drainage. Geochim. Cosmochim. Acta 63, 3407-3416.

Yu, J.-Y., Park, M., Kim, J., 2002. Solubilities of synthetic schwertmannite and ferrihydrite. Geochem. J. 36, 119-132 